\title{
EFFECT OF ENCASEMENT ON THE BEHAVIOR OF GRANULAR PILES
}

\author{
Abdel-Fattah A. Youssef ${ }^{1}$, Ahmed M. Abdel-Galil ${ }^{1}$, Enas A. Emam ${ }^{2 *}$ \\ ${ }^{l}$ Civil Engineering Department, Faculty of Engineering, Menoufia University, Menoufia, Egypt. \\ ${ }^{2}$ Civil Engineering Department, Higher Institute of Engineering and Technology, Menoufia, Egypt. \\ *(Corresponding author: Dr.EnasEmam@Yahoo.com)
}

\begin{abstract}
Granular piles in very soft soils may not drive significant load capacity because of the low lateral confinement offered by soft soils, which leads to excessive bulging and squeezing of soft clay into the void space. To overcome this problem, geosynthetic encasement of individual granular piles is an effective method to improve the performance of the granular piles as providing additional confinement. The use of recycled aggregates as a pile material offers a practical alternative from economic, technical, and environmental standpoints. This is due to their suitable engineering properties, which allow them to be used as additional materials in several geotechnical applications. The main objective of this research is to investigate the behavior of encased granular piles using different types of aggregate as a granular pile material (basalt, crushed concrete, crushed red bricks and crushed ceramic). In the present research, three series of laboratory model tests using the unit cell concept were performed to investigate the effect of encasement on the behavior of granular piles. For comparison purposes, ordinary granular piles were also tested and evaluated. The results show that the ultimate load capacity of the soft clay soil increased by using the encased granular piles. Economically, using partial encasement is more efficient than using total encasement.
\end{abstract}

Keywords: Granular pile; very soft clay; recycled aggregates; bearing capacity; floating; end bearing; encasement; Geogrid; geotextile.

\section{Introduction}

Due to the increasing necessity of land, the need to use marginal sites with poor engineering properties has become mandatory. Granular piles are one of the most applicable techniques for improving soil conditions. This technique is assessed as more useful and economic than other techniques .Granular piles have been widely used to support structures on soft clay soil by increasing bearing capacity and reducing settlement, and accelerating consolidation of soft soil $[1,2,3,4]$. However, when the soft soils are extremely weak, the granular piles are not operative to improve their load capacity. It is well-known that the granular piles originate their load-carrying capacity from the lateral confining pressure provided by surrounding soil $[5,1,6]$. When granular piles are installed in very soft soils or in layered soils where the top layer is very soft, they may not drive significant load capacity owing to low lateral confinement offered by soft soils, which leads to excessive bulging and also squeezing of soft clay into the void space of aggregates [7]. According to German regulations, the application of granular piles is generally limited to soils with undrained shear strength $\mathrm{Cu}>15-25 \mathrm{kN} / \mathrm{m}^{2}$ [8]. Below this strength, the lateral support provided by surrounding soil may be insufficient to prevent column failure through excessive radial expansion [9]. Geosynthetic encasement of individual granular piles is an effective method to improve the performance of the granular piles installed in very soft soils by providing additional confinement. As a result, the capacity and stiffness of the columns can be increased and the settlement of the soil strata can be reduced. Ali et al., (2014) [10] studied the behavior of reinforced stone columns in soft soils. Laboratory model tests have been carried out on floating and fully penetrating single piles with and without geotextile to find out the effect of encasement, $1 / \mathrm{d}$ ratio, and diameter of the column on bearing capacity. Since stone columns having lengths more than six times their diameter do not contribute much to bearing capacity, therefore, floating columns should be preferred in situations where hard strata are at a depth more than this 
length. The columns should be wrapped around with some geosynthetic material, by doing so, the bearing capacity of the improved ground is increased by manifolds. Since bulging of stone columns takes place only in the upper portion due to lack of lateral pressure, hence providing geosynthetic in that portion may also be equally beneficial.

Murugesan and Rajagopal, (2007) [11] investigated the load-carrying capacity of encased granular piles through laboratory model tests performed in a rigid unit cell. They concluded that, unlike the conventional granular piles, the geosynthetic encased granular piles did not show a strain response.

The hoop strains in the geosynthetic encasement are maximum near the top surface and decrease with depth (Murugesan and Rajagopal, 2010) [12].

The strain levels were observed to be less for large pile diameters. The performance of granular piles encased to partial heights is very close to that of fully encased granular piles, but they exhibited strains response when subjected to pressure beyond a particular load. It is found that reinforcing granular pile with vertical circumferential nails at the top to a depth equal to three times the diameter of granular pile, will be adequate to prevent the pile from excessive bulging and to improve its loadcarrying capacity substantially [13]. With increasing the length of encasement, the bearing capacity and stiffness of the stone column increase. The effective length of encasement was 3-4 times the diameter of granular piles based on consideration of performance and economy [14].

The unit cell concept includes one pile and the contributory surrounding soil. The unit cell approach is the basic theory for granular piles proposed by Priebe [2], which is also known as Priebe Method. Many researchers have used the unit cell concept $[15,16,17,18,19]$. Priebe assumed that this unit is surrounded by a rigid frictionless wall and that the vertical deformations are equal in every plane. Also, the pile is stiff and incompressible, whereas the surrounding soil is elastic [2]. The stress distribution in the soil is isotropic, and a rigid base plate is above the granular pile. Also, the load transferred to the subsurface soil is uniform.

In practice, a sand pad with a thickness of $30 \mathrm{~cm}$ or more is used on the top of the soil improved by granular piles for drainage purposes, as well as distribution of the stresses coming from superstructures [20].

As the result of increasing waste materials from demolition activities as well as the problem of reduction of natural aggregate resources, using alternative aggregates to the natural aggregates for granular piles is considered. An extensive suite of geotechnical and environmental aspects has been undertaken by many researchers to study the potential of using recycled and waste materials [21, $22,23,24,25]$. RA (recycled aggregate) may be utilized as a coarse base and sub-base layer for lowvolume roads [26]. Also, RA was used as granular piles material to improve the soft clay by many researchers [27].

In this research, the effect of encasement on the behavior of granular piles using different pile materials was studied.

\section{Experimental Program}

Laboratory model tests were conducted on very soft clay soil reinforced by encased floating and encased end bearing granular piles. Tests were performed after reinforcing the very soft clay soil by introducing the granular piles with recycled materials (crushed concrete, crushed ceramics, and crushed red brick) as well as natural aggregate (basalt). The dimensions of molds were designed using the unit cell concept. The main variables in this study are; granular pile material, pile type (floating and end bearing), type of encasement, and length of the encasement. The details of the tests performed are presented in Table (1).

\section{Properties of Materials}

Materials used for this study are clay, aggregates, and sand having the following properties:

\section{Soil Used}

Obtaining undisturbed very soft clay samples from the site is too difficult. Therefore, the very soft clay has been excavated from a construction site then, prepared in the laboratory. The procedures of preparing soft clay in the laboratory are described in section (4.1). The classification of very soft clay is $\mathrm{CH}$ as per USCS. The main properties of the very soft clay are shown in Table (2). 
Table (1): Details of tested samples of (Very soft clay $C=0.04 \mathrm{~kg} / \mathrm{cm}^{2}$ ).

\begin{tabular}{|c|c|c|c|c|c|c|c|c|c|c|}
\hline \multirow{2}{*}{$\begin{array}{l}\text { Test } \\
\text { No. }\end{array}$} & \multirow[b]{2}{*}{ Test Description } & \multicolumn{7}{|c|}{ Pile properties } & \multicolumn{2}{|c|}{ Mold Dim. } \\
\hline & & $\begin{array}{c}\mathbf{d}_{\mathrm{p}} \\
(\mathrm{cm})\end{array}$ & $\begin{array}{l}\mathrm{Ar} \\
(\%)\end{array}$ & $\begin{array}{c}\mathbf{L} \\
(\mathrm{cm})\end{array}$ & $\begin{array}{c}\mathbf{H} \\
(\mathrm{cm})\end{array}$ & $\mathbf{L} / \mathbf{H}$ & L/d & Pile material & $\begin{array}{c}d_{M} \\
(\mathrm{~cm})\end{array}$ & $\begin{array}{c}\mathbf{h}_{M} \\
(\mathrm{~cm})\end{array}$ \\
\hline \multicolumn{11}{|c|}{ Series (1) } \\
\hline 1 & Very soft clay & -- & -- & -- & \multirow[b]{2}{*}{30} & -- & -- & \multirow[b]{2}{*}{ Without } & \multirow{6}{*}{15} & \multirow{2}{*}{35} \\
\hline 2 & $\begin{array}{c}\text { Very soft clay + sand } \\
\text { pad }\end{array}$ & -- & -- & -- & & -- & -- & & & \\
\hline 3 & \multirow{4}{*}{$\begin{array}{l}\text { Very soft clay }+ \text { sand } \\
\text { pad end bearing pile }\end{array}$} & \multirow{4}{*}{5} & \multirow{4}{*}{15} & \multirow{4}{*}{30} & \multirow{4}{*}{30} & \multirow{4}{*}{1} & & basalt & & \multirow{4}{*}{35} \\
\hline 4 & & & & & & & & Cr. concrete & & \\
\hline 5 & & & & & & & & Cr. red brick & & \\
\hline 6 & & & & & & & & Cr. ceramic & & \\
\hline 7 & \multirow{4}{*}{$\begin{array}{c}\text { Very soft clay + sand } \\
\text { pad + floating pile }\end{array}$} & \multirow{4}{*}{5} & \multirow{4}{*}{15} & \multirow{4}{*}{45} & \multirow{4}{*}{60} & \multirow{4}{*}{0.75} & \multirow{4}{*}{9} & basalt & \multirow{4}{*}{15} & \\
\hline 8 & & & & & & & & Cr. concrete & & 65 \\
\hline 9 & & & & & & & & Cr. red brick & & 05 \\
\hline 10 & & & & & & & & Cr. ceramic & & \\
\hline & & & & Series & & & & & & \\
\hline 11 & Very soft clay + sand & & & & & & & basalt & & \\
\hline 12 & pad + floating pile + & & & & & & & Cr. concrete & & \\
\hline 13 & Total geotextile & & & & & & & Cr. red brick & & \\
\hline 14 & encasement & 5 & 15 & 15 & 60 & 075 & 0 & Cr. ceramic & & 65 \\
\hline 15 & Very soft clay + sand & 5 & 15 & 45 & 60 & 0.75 & 9 & basalt & 15 & 65 \\
\hline 16 & pad + floating pile+ & & & & & & & Cr. concrete & & \\
\hline 17 & partial geotextile & & & & & & & Cr. red brick & & \\
\hline 18 & encasement & & & & & & & Cr. ceramic & & \\
\hline 19 & Very soft clay + sand & & & & & & & basalt & & \\
\hline 20 & pad + floating pile+ & & & & & & & Cr. concrete & & \\
\hline 21 & total woven geogrid & & & & & & & Cr. red brick & & \\
\hline 22 & encasement & 5 & 15 & 45 & 60 & 075 & 9 & Cr. ceramic & 15 & 65 \\
\hline 23 & Very soft clay + sand & $J$ & 15 & 45 & 00 & 0.12 & 9 & basalt & 15 & סJ \\
\hline 24 & pad + floating pile+ & & & & & & & Cr. concrete & & \\
\hline 25 & partial woven geogrid & & & & & & & Cr. red brick & & \\
\hline 26 & encasement & & & & & & & Cr. ceramic & & \\
\hline & & & & Series & & & & & & \\
\hline 27 & Very soft clay + sand & & & & & & & basalt & & \\
\hline 28 & pad + end bearing pile + & 5 & 15 & 30 & 30 & 1 & 6 & Cr. concrete & 15 & 35 \\
\hline 29 & Geotex. enc. & 5 & & & & 1 & 0 & Cr. red brick & & 35 \\
\hline 30 & & & & & & & & Cr. ceramic & & \\
\hline 31 & Very soft clay + sand & & & & & & & basalt & & \\
\hline 32 & pad + floating pile+ & 5 & & & 20 & 1 & ( & Cr. concrete & & 25 \\
\hline 33 & woven geogrid & 5 & 15 & 30 & 30 & 1 & 6 & Cr. red brick & & 35 \\
\hline 34 & encasement & & & & & & & Cr. ceramic & & \\
\hline
\end{tabular}


Table (2): Main properties of tested Very Soft clay.

\begin{tabular}{lcc}
\hline \multicolumn{1}{c}{ Properties } & $\begin{array}{c}\text { Very soft } \\
\text { clay }\end{array}$ \\
\hline Water content & $(\%)$ & $60 \% \pm 0.5 \%$ \\
\hline Specific gravity & & 2.64 \\
\hline $\begin{array}{l}\text { Bulk density } \\
\left(\mathrm{gm} / \mathrm{cm}^{3}\right)\end{array}$ & 1.61 \\
\hline Liquid limit "L.L." & $(\%)$ & 62 \\
\hline Plastic limit "PL" & $(\%)$ & 28 \\
\hline Plasticity index "I" & $(\%)$ & 34 \\
\hline $\begin{array}{l}\text { Cohesion "C" } \\
\left(K g / \mathrm{cm}^{2}\right)\end{array}$ & & 0.04 \\
\hline $\begin{array}{l}\text { Angle of internal friction " }{ }^{\prime} \\
(D e g .)\end{array}$ & $\phi \approx 0.0^{\circ}$ \\
\hline
\end{tabular}

\section{Aggregates}

Three types of recycled aggregates (crushed concrete, crushed ceramics, and crushed red brick), as well as one type of natural aggregate (basalt), were used in this study. The size distribution of the aggregate is ranged between $0.1 \mathrm{~mm}$ to $1 \mathrm{~mm}$ (about one-sixth of the pile diameter) as shown in Fig. (1). Three types of recycled aggregates and the natural aggregate used is well graded as per USCS. The angle of internal friction of each type of aggregates has been determined using the direct shear test as shown in Fig. (2). The main properties of aggregates for the granular pile are illustrated in Table (3).

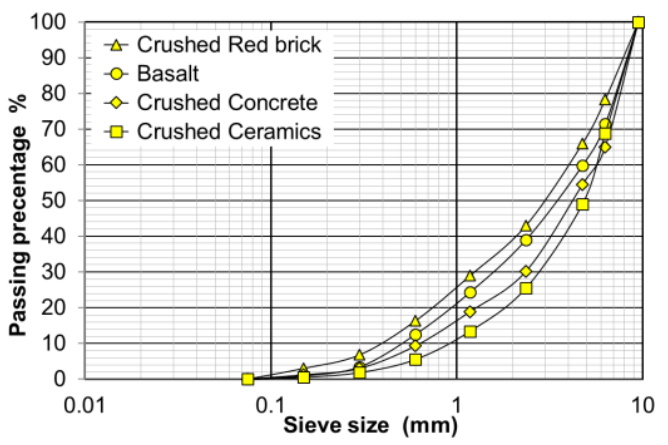

Figure (1): Grain size distribution of granular pile materials.

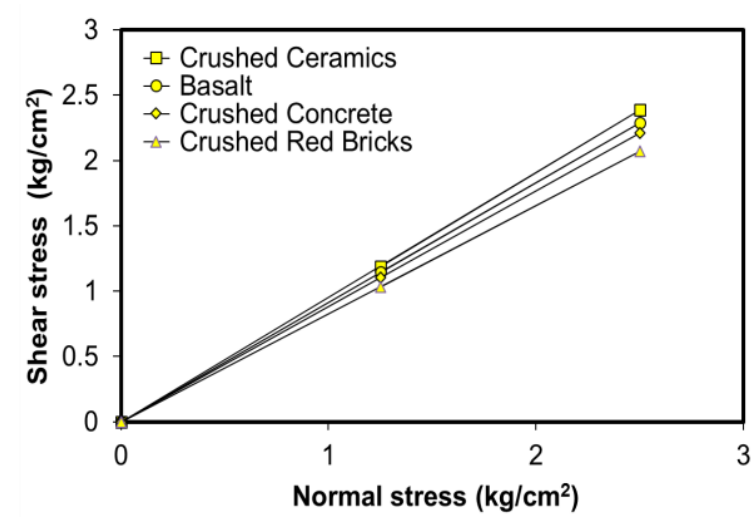

Figure (2): Normal stress to shear stress relationship for granular pile materials.
Table (3): Main properties of pile materials.

\begin{tabular}{c|cccc} 
Properties & Basalt & $\begin{array}{c}\text { Crushed } \\
\text { ceramic }\end{array}$ & $\begin{array}{c}\text { Crushed } \\
\text { concrete }\end{array}$ & $\begin{array}{c}\text { Crushed } \\
\text { Red } \\
\text { bricks }\end{array}$ \\
\hline $\begin{array}{c}\text { The angle of } \\
\text { internal } \\
\text { friction } \\
(\phi)\end{array}$ & 42.5 & $43.73^{\circ}$ & $41.5^{\circ}$ & $39.5^{\circ}$ \\
\hline $\begin{array}{c}\text { Specific } \\
\text { gravity }\end{array}$ & 2.79 & 2.3 & 2.4 & 2.1 \\
\hline $\begin{array}{c}\text { Max. dry } \\
\text { density } \\
\left(\mathrm{gm} / \mathrm{cm}^{3}\right)\end{array}$ & 1.68 & 1.37 & 1.54 & 1.31 \\
\hline $\mathrm{Cu}$ & 13.2 & 11.7 & 10.16 & 10 \\
\hline $\mathrm{Cc}$ & 1.38 & 2.49 & 1.35 & 1.06
\end{tabular}

\section{Sand}

The used sand is classified as (SP), poorly graded sand as per USCS. The angle of internal friction $=36^{\circ}$ has been determined from the direct shear test.

\section{Encasement Materials}

Two different types of encasement materials were used to encase (reinforce) the granular piles. They were woven geogrid and geotextile. The main properties of the two types of encasement materials according Specification data of manufacturer company (Tensar) are presented in Tables (4) and (5).

Table (4): The main properties of woven geogrid.

\begin{tabular}{lcc}
\hline \multicolumn{1}{c}{ Specification data } & CE131 \\
\hline Physical properties: & & \\
\hline Form & $(\mathrm{m})$ & Sheet \\
\hline Width & $(\mathrm{m})$ & 30 \\
\hline Length & $(\mathrm{mm})$ & $27 \times 27$ \\
\hline Mesh aperture size & $(\mathrm{mm})$ & 5.2 \\
\hline Mesh thickness & $\left(\mathrm{g} / \mathrm{m}^{2}\right)$ & 660 \\
\hline Structure weight & & Black \\
\hline Color & & HD- \\
\hline Polymer & & polyethylene \\
\hline Tensile strength: & & \\
Tensile strength & $(\mathrm{KN} / \mathrm{m})$ & 5.8 \\
Extension at max load & $(\%)$ & 16.5 \\
Load at 10\% extension & $(\mathrm{KN} / \mathrm{m})$ & 5.2 \\
Elongation at $1 / 2$ peak & $(\%)$ & 3.7 \\
strength & & \\
\hline
\end{tabular}


Table (5): The main properties of geotextile.

\begin{tabular}{lcc}
\hline Product reference & & 400/50 \\
\hline Polymer type & & Polyester \\
\hline MD Strength (minimum) & $(\mathrm{KN} / \mathrm{m})$ & 400 \\
\hline TD Strength (minimum) & $(\mathrm{KN} / \mathrm{m})$ & 50 \\
\hline Thickness (typical) & $(\mathrm{mm})$ & 2.5 \\
\hline $\begin{array}{l}\text { Pore Size BS6906: Part } 2 \\
1969\end{array}$ & $(\mathrm{Mm})$ & $>400$ \\
\hline $\begin{array}{l}\text { Water FlowBS6906: Part } \\
\text { 1969 }\end{array}$ & $(\mathrm{mm})$ & 0 \\
\hline $\begin{array}{l}\text { Breakthrough Head Flow } \\
\text { Rate (typical) }\end{array}$ & $\left(\mathrm{l} / \mathrm{m}^{2} / \mathrm{sec}\right)$ & 115.58 \\
\hline weight (approximate) & $\left(\mathrm{g} / \mathrm{m}^{2}\right)$ & 800 \\
\hline Rol width (nominal) & $(\mathrm{m})$ & 4.4 \\
\hline Rol length (minimum) & $(\mathrm{m})$ & 100 \\
\hline Rol weight (approximate) & $(\mathrm{Kg})$ & 355 \\
\hline
\end{tabular}

\section{Preparation of Laboratory Specimens}

An identical technique was used to prepare all the specimens. The clay bed was prepared then; the granular pile was installed as follows.

\subsection{Preparation of Soft Clay Bed}

The soft clay bed was prepared by using a quantity of clay taken from a site under construction in shebin el kom city. It was dried in the oven for 24 hours (at $105-110^{\circ} \mathrm{C}$ ) and pulverized. The clay was sieved through sieve No. $200(0.074 \mathrm{~mm})$. Clay used was passed from 0.074 $\mathrm{mm}$ sieve then; it stored in plastic barrels' court closures. After that, the clay was mixed with predetermined quantity of water to achieve a required water content (chosen as $60 \%$ to provide shear strength of $0.04 \mathrm{~kg} / \mathrm{cm}^{2}$ based on test results of van shear test). A mechanical mixer was used for a well-kneaded clay sample. Two polypropylene molds of $150 \mathrm{~mm}$ diameter and various heights were used. The inner surface of each mold wall was covered with a very thin polythene sheet over a thin coat of grease that was applied to reduce the friction between clay and the tank wall. The soft clay soil was filled in the mold in layers $50 \mathrm{~mm}$ thick with measured quantity by weight then, compacted manually to achieve $1.61 \mathrm{t} / \mathrm{m}^{3}$ density. Molds were kept covered for 24 hours to achieve uniform consistency. After 24 hours of hydration, the soil is checked for water content. The proposed height of soft clay in the mold was lower than the mold heights by about $5 \mathrm{~cm}$ to put a $3 \mathrm{~cm}$ sand cushion layer after pile installation.

\subsection{Granular Pile Installation}

4.2.1. Installation of Granular Piles without Encasement

Before installation of the piles, the shear strength of the prepared bed was checked by vane shear test. To install piles in a very soft clay bed (with shear strength equal to $0.04 \mathrm{~kg} / \mathrm{cm}^{2}$ ), the displacement method was used.

- Thin locked-end PVC pipes (of 50 or $75 \mathrm{~mm}$ diameter) were used which were locked with a sticker.

- Slight grease was applied on the outer surface of the pipe for easy penetration without any significant disturbance to the surrounding soil.

- It was pushed into the clay bed up to the required depth, then; the end of the pipe was opened using the compaction rod.

- Pile materials were charged into the hole in layers of $50 \mathrm{~mm}$ with a measured quantity of each pile material to achieve a uniform density for each type of pile material.

- The pipe was then raised in stages ensuring a minimum of $25 \mathrm{~mm}$ penetration below the top level of the placed aggregate.

- Compaction was given with a 2-kg circular steel tamper with 10 blows of $100 \mathrm{~mm}$ drop to each layer to ensure there is no significant lateral bulging of the column.

\subsubsection{Installation of Granular Piles with Encasement}

To install the granular piles with geogrid or geotextile encasements (even partially or fully encasement), the displacement method was used. The steps were the same as pile installation by the displacement method, but the encasement (even partially or fully encasement) was fixed on the outer surface of the PVC pipe before installation.

\section{Test Procedures}

After installation of the granular pile, a sand layer of $30 \mathrm{~mm}$ thickness was placed on the top of a sample as a sand pad. After that, the samples were loaded through a circular steel footing of $130 \mathrm{~mm}$ diameter and thickness equal to $20 \mathrm{~mm}$. The load was applied through a proving ring of $5 \mathrm{kN}$ capacity. The load increments are $5 \mathrm{~kg}$ for each interval. The settlement of the footing was recorded using two dial gauges of $0.01 \mathrm{~mm}$ accuracy set on the footing. The load increment was done after obtaining the steady condition of the reading of the dial gauge. The increment of load on the footing is continued until settlement equals 0.2 the footing width (B). A complete test setup arrangement and schematic view of typical granular pile foundation for the test has been shown in Fig. (3). 


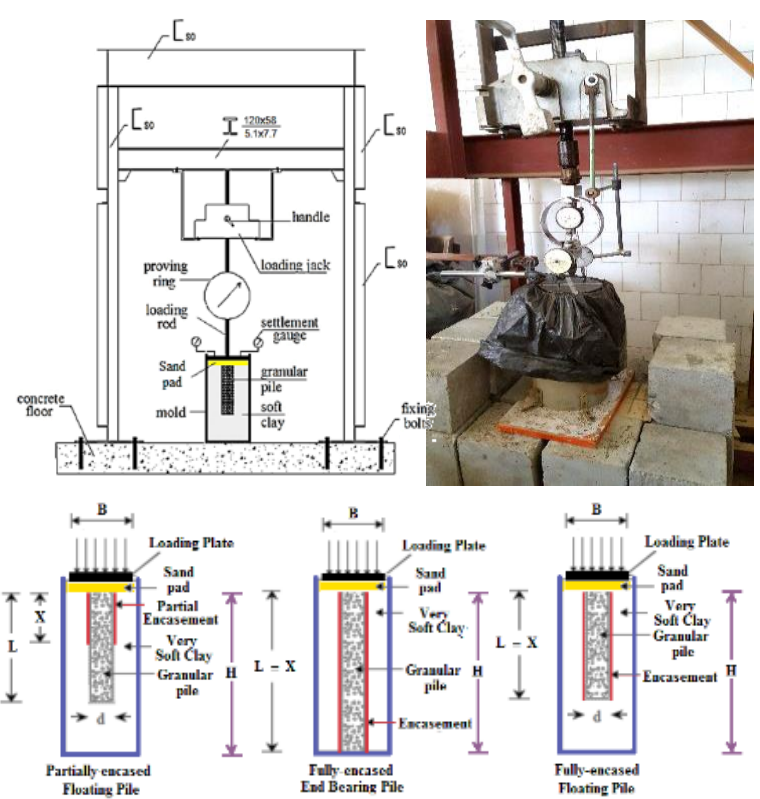

Figure (3): A complete schematic of the test setup.

\section{Results and Discussion}

Laboratory model tests were conducted to investigate the effect of reinforcing soft clay soil by using encased floating granular piles. Test results are driven in terms of load-carrying capacity and settlement. When the entire area is loaded, failure does not take place even for settlement equal to 26 $\mathrm{mm}$ ( 0.2 footing width for all tested specimens), which indicates that the soft soil follows the punching failure, which is characterized by no peak failure point or potential surface heave due to the confinement of unit cell. The $0.1 \mathrm{~B}$ method was used to define the ultimate load.

\subsection{Effect of Using the Sand Pad}

The sand cushion layer without using granular pile reduced the settlement values. It increased the loadcarrying capacity by about $100 \%$ due to the redistribution of the loads, which caused a reduction in the concentration of the stresses as in Fig. (4).

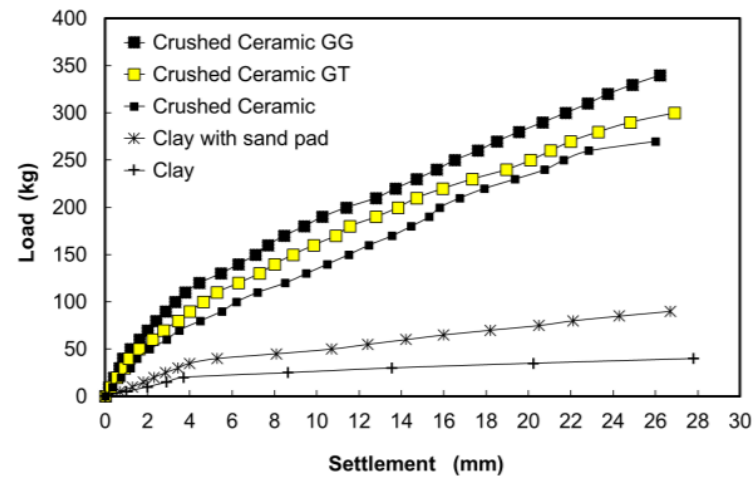

Figure (5): Effect of total encasement types on the load-settlement curve of very soft clay reinforced with end bearing crushed ceramic pile.

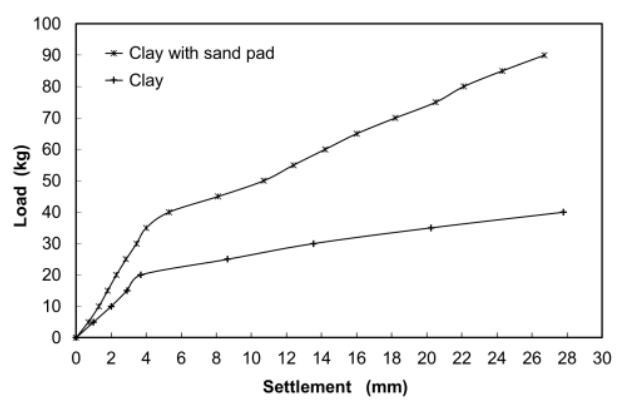

Figure (4): Effect of using the sand pad on the load-settlement curve of very soft clay.

\subsection{End Bearing Piles}

Eight experiments were conducted to study the effect of using total encased geotextile and geogrid end bearing granular piles. Figures (5) to (8) show the influence of using encasement on very soft clay soil reinforced with end bearing encased granular piles. Using encasement increases the load-carrying capacity of very soft clay.

Test results indicated that using encased end bearing granular pile is better than using a conventional granular pile. Using either geotextile or geogrid encasement improves the very soft clay soil for all pile materials used.

Using geogrid encasement was more useful than using geotextile for the total encased end bearing granular pile. That may refer to that the higher stiffness of geogrid facilitates the maximum transfer of load to the bottom of the granular pile which is resting on hard strata. Thus, the higher stiffness of the geogrid is fully utilized by mobilization of hoop stresses and the composite ground is better able to support the larger applied load which is in agreement Ali et al., 2014 [10]. On the other hand, owing to the lower stiffness of geotextile, granular piles undergo relatively higher bulging and consequently settle more.

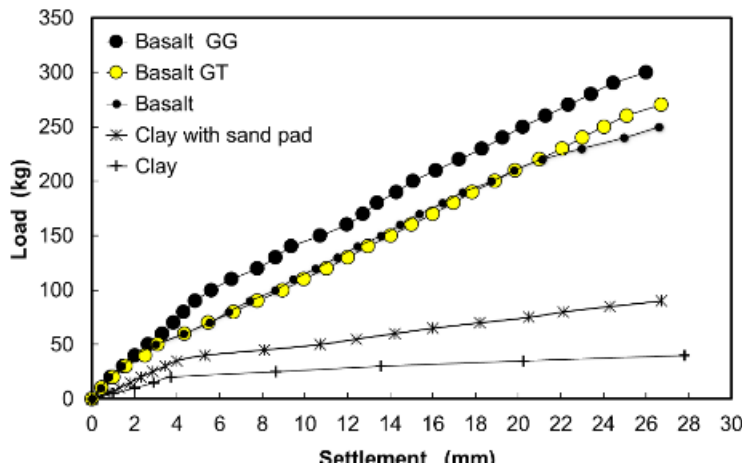

Figure (6): Effect of total encasement types on the load-settlement curve of very soft clay reinforced with end bearing basalt pile. 


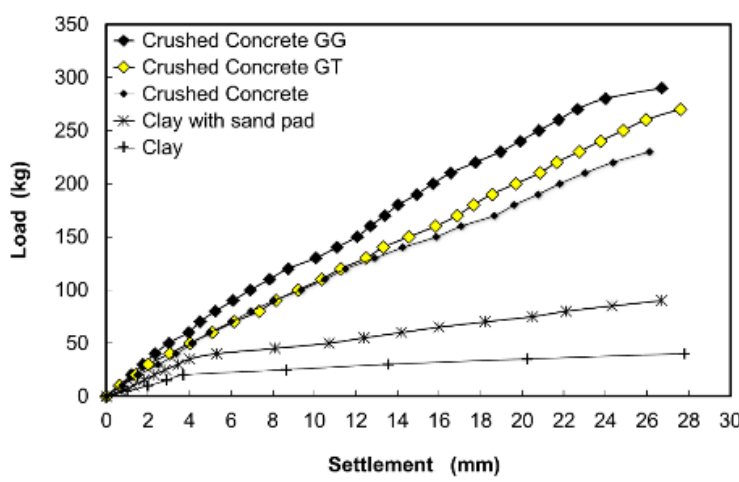

Figure (7): Effect of total encasement types on the load-settlement curve of very soft clay reinforced with end bearing crushed concrete pile.

It is noticed from figures (9) to (12) that the value of the BCR (bearing capacity ratio) is found to increase as footing settlement increase for all types of encasement. The improvement in the bearing capacity is greater for geogrid $(\mathrm{GG})$ than for geotextile (GT) encasement for any pile material. From Figures (13) to (16), The ultimate carrying capacity of end bearing piles encased by geogrid with basalt, crushed ceramic, crushed concrete, and crushed red brick as granular pile materials increase by about $18.1 \%, 26.6 \%, 23.5 \%$, and $19.3 \%$, respectively compared to the very soft clay reinforced with conventional granular piles.

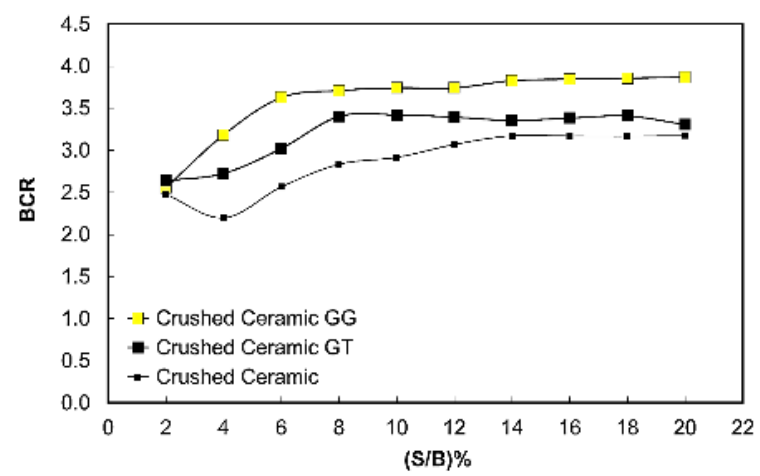

Figure (9): Effect of total encasement types on the bearing capacity ratio -settlement ratio curve of very soft clay reinforced with end bearing crushed ceramic pile.

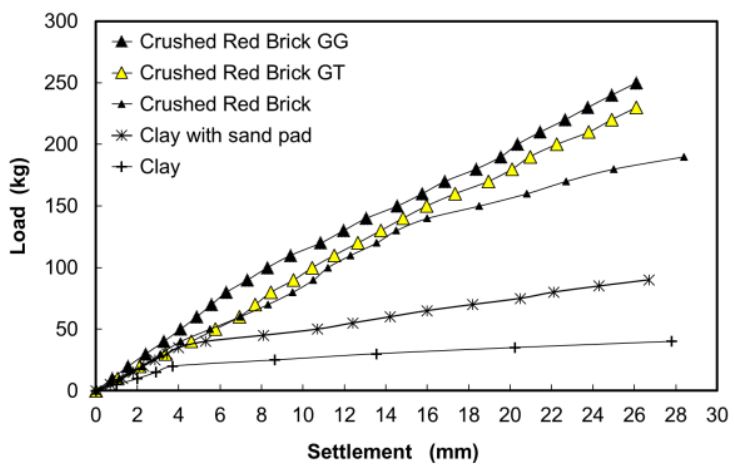

Figure (8): Effect of total encasement types on the load-settlement curve of very soft clay reinforced with end bearing crushed red brick pile.

The ultimate carrying capacity of end bearing piles encased by geotextile with basalt, crushed ceramic, crushed concrete, and crushed red brick as granular pile materials increased by about $0.3 \%, 14.4 \%$, $1.7 \%$, and $5.9 \%$, respectively compared to the very soft clay reinforced with conventional granular piles. Comparing to using geotextile, using geogrid as encasement for end bearing granular piles increased the carrying capacity by about $17.6 \%$, $10.6 \%, 21.4 \%$, and 12.6 for basalt, crushed ceramic, crushed concrete, and crushed red brick, respectively.

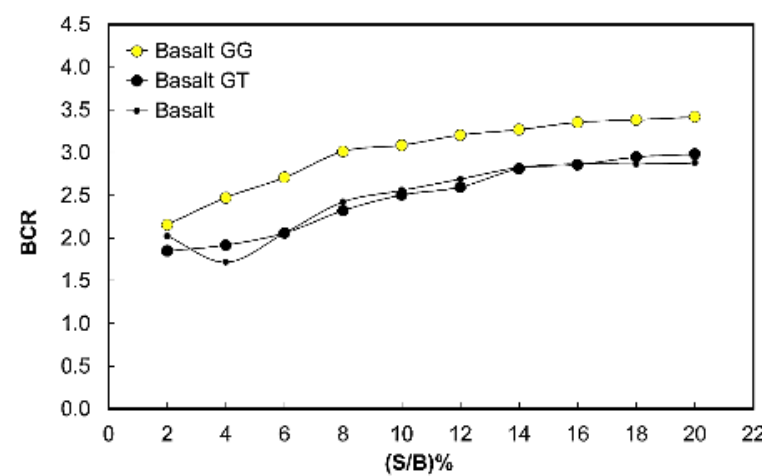

Figure (10): Effect of total encasement types on the bearing capacity ratio -settlement ratio curve of very soft clay reinforced with end bearing basalt pile. 


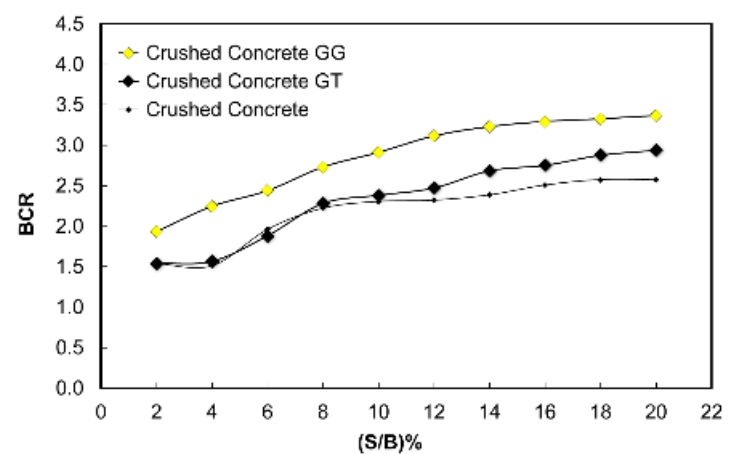

Figure (11): Effect of total encasement types on the bearing capacity ratio -settlement ratio curve of very soft clay reinforced with end bearing crushed concrete pile.

\subsection{Floating Granular Pile}

Sixteen experiments were conducted to study the effect of using partial $(\mathrm{X}=0.5 \mathrm{~L})$ and total $(\mathrm{X}=\mathrm{L})$ geotextile and geogrid encased floating granular piles with different pile materials where $X$ was the encasement length. Figures (16) to (23) show the influence of using encasement on the soft clay soil. Using encasement improves the load-carrying capacity of very soft clay soil. Test results showed that using encased granular pile is better than using a conventional granular pile even with partial or total encasement. Using either geotextile or geogrid encasement improves the very soft clay soil for all

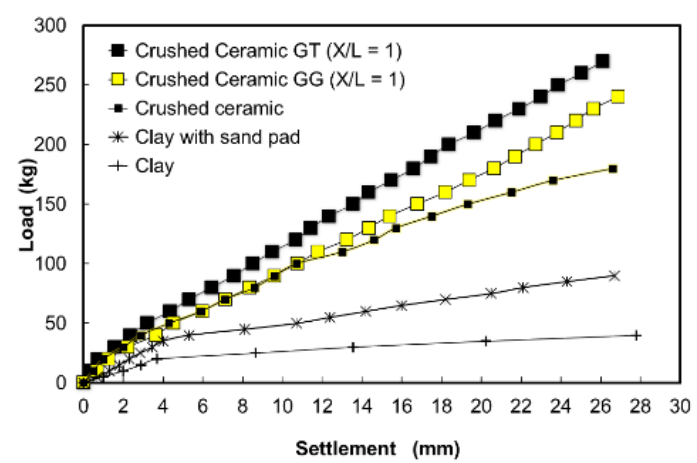

Figure (13): Effect of encasement type on the loadsettlement curve of very soft clay reinforced with total encased floating crushed ceramic pile.

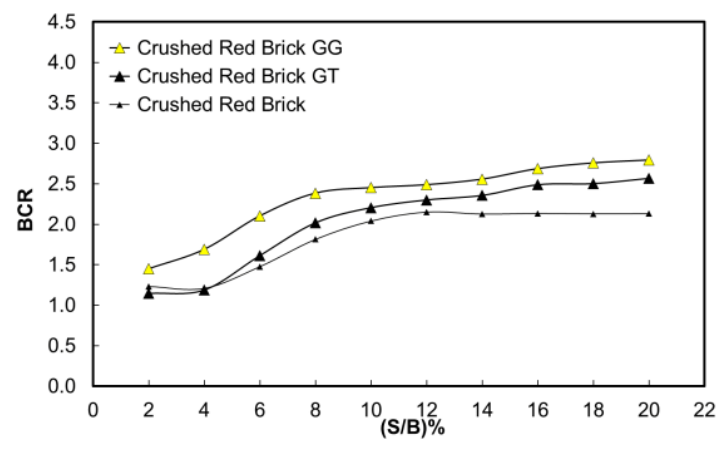

Figure (12): Effect of total encasement types on the bearing capacity ratio -settlement ratio curve of very soft clay reinforced with end bearing crushed red brick pile.

pile materials used. Using geotextile encasement was more beneficial than using geogrid as total or partial encasement. That may refer to a stiffer geogrid that transfers the maximum load to the bottom of the granular pile and only a small amount of load is transferred to the sides through column bulging. As the soil is soft, high load transfer at the bottom leads to easy penetration of granular pile at a relatively smaller applied load. On other hand, geotextile transfers load to the sides as well as the bottom and thus supports a greater applied load which satisfies Ali et al., 2014 [10] and Emam, 2017 [19].

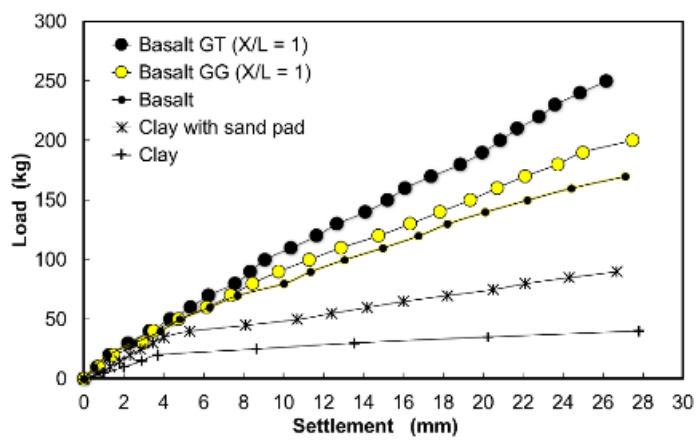

Figure (14): Effect of encasement type on the loadsettlement curve of very soft clay reinforced with total encased floating crushed ceramic pile. 


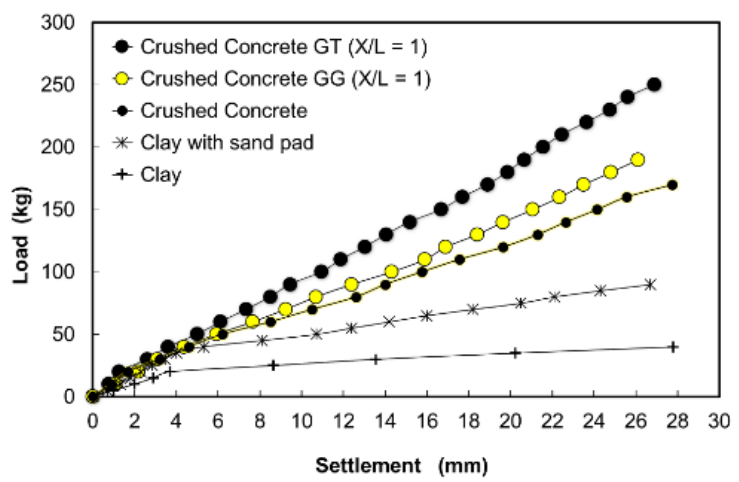

Figure (15): Effect of encasement type on the loadsettlement curve of very soft clay reinforced with total encased floating crushed ceramic pile.

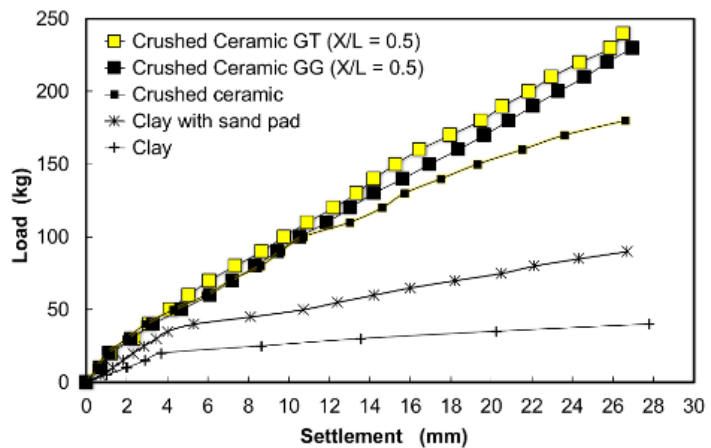

Figure (17): Effect of encasement type on the loadsettlement curve of very soft clay reinforced with partial encased floating crushed ceramic pile.

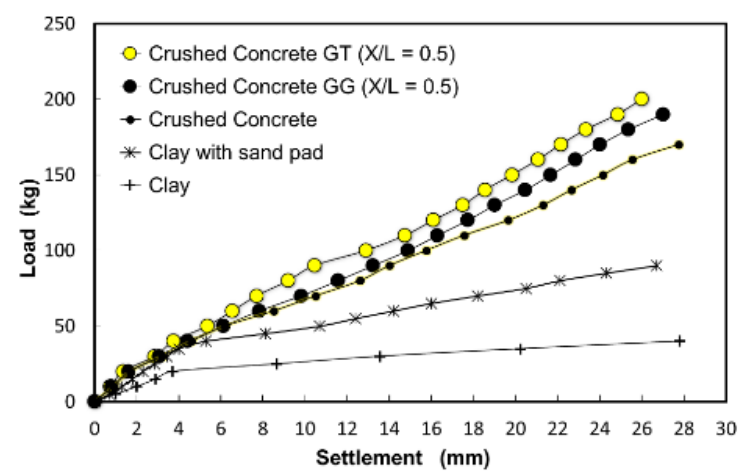

Figure (19): Effect of encasement type on the loadsettlement curve of very soft clay reinforced with partial encased floating crushed ceramic pile.

It is noticed from figures (21) to (24) the value of the BCR is found to increase as footing settlement increase for all types of encasement and whatever the length of the encasement is total or

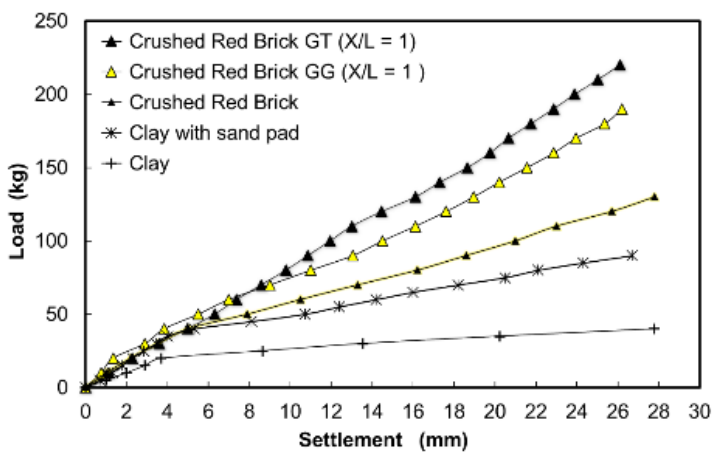

Figure (16): Effect of encasement type on the loadsettlement curve of very soft clay reinforced with total encased floating crushed ceramic pile.

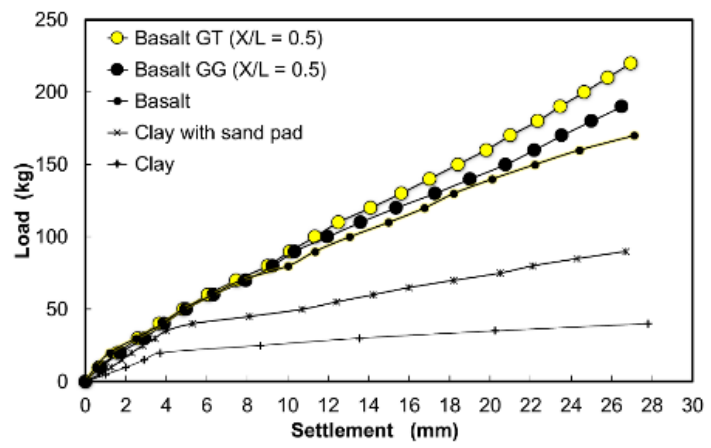

Figure (18): Effect of encasement type on the loadsettlement curve of very soft clay reinforced with partial encased floating crushed ceramic pile.

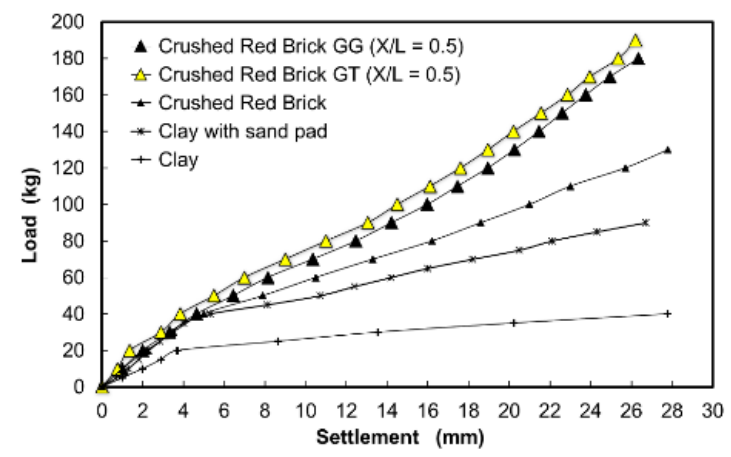

Figure (20): Effect of encasement type on the loadsettlement curve of very soft clay reinforced with partial encased floating crushed ceramic pile.

partial encased. The improvement in the bearing capacity is greater for geotextile than for geogrid encasement for any length of the encasement. 


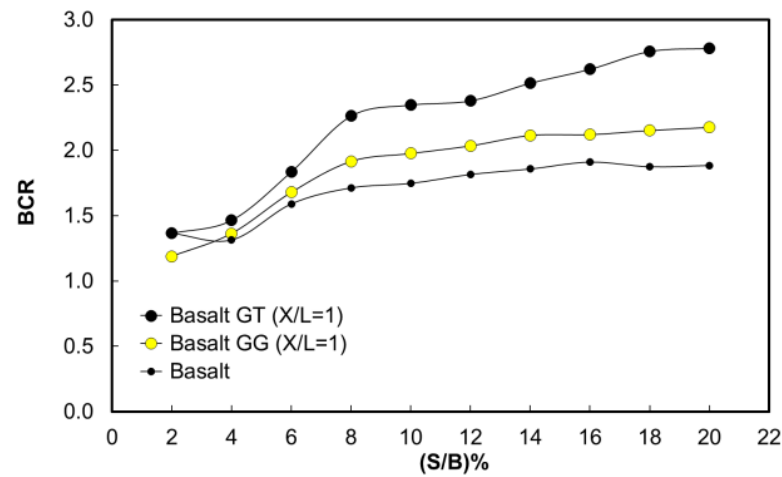

Figure (21): Effect of encasement type on the bearing capacity ratio -settlement ratio curve of very soft clay reinforced with floating basalt pile.

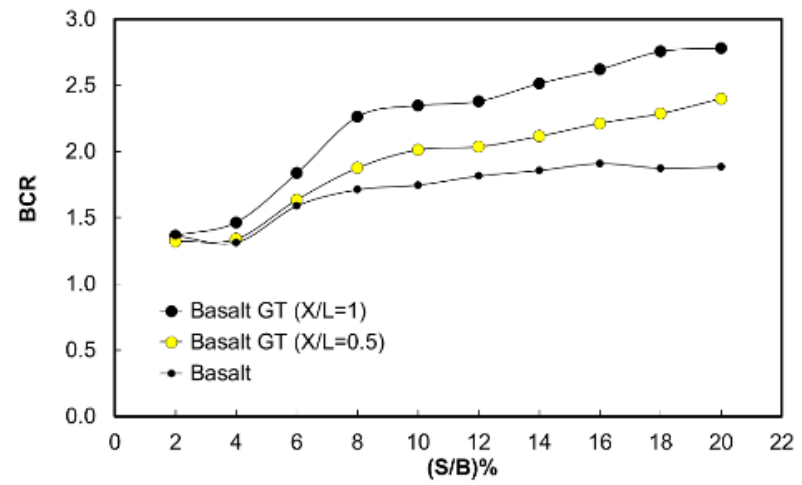

Figure (23): Effect of geotextile encasement length on the bearing capacity ratio -settlement ratio curve of very soft clay reinforced with floating basalt pile.

From Fig. (25), The ultimate bearing capacity of floating granular piles encased by total woven geogrid encasement with basalt, crushed ceramic, crushed concrete, and crushed red brick as granular pile materials increase by about $11 \%, 8.9 \%, 11.9 \%$, and $30.3 \%$, respectively compared to the very soft clay reinforced with conventional granular piles. The ultimate bearing capacity of floating granular piles encased by total geotextile encasement with basalt, crushed ceramic, crushed concrete, and crushed red brick as granular pile materials increase by about $33.1 \%, 31.6 \%, 44.8 \%$, and $59.7 \%$, respectively compared to the very soft clay reinforced with conventional granular piles .

The ultimate bearing capacity of encased floating granular piles with basalt, crushed ceramic, crushed concrete, and crushed red brick as granular pile materials with partial woven geogrid encasement increase by about $6.4 \%, 6.8 \%, 7 \%$, and $20.2 \%$, respectively compared to the very soft clay reinforced with conventional granular piles. The ultimate bearing capacity of encased floating

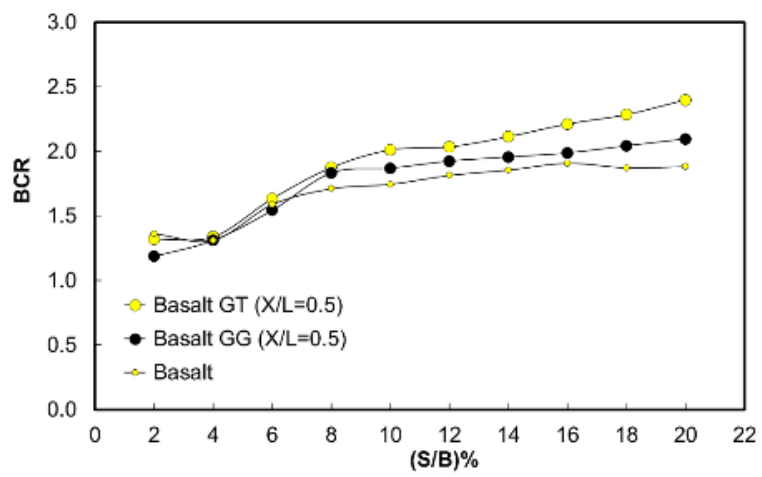

Figure (22): Effect of encasement type on the bearing capacity ratio -settlement ratio curve of very soft clay reinforced with partial encased floating basalt pile.

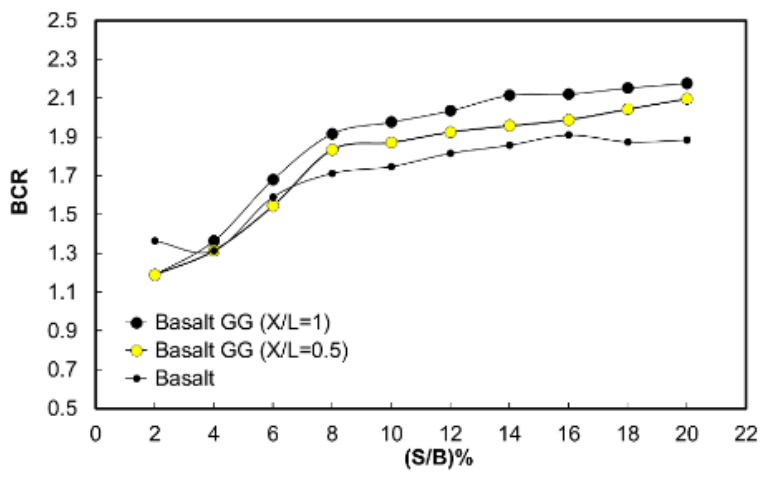

Figure (24): Effect of geogrid encasement length on the bearing capacity ratio -settlement ratio curve of very soft clay reinforced with floating basalt pile.

granular piles with basalt, crushed ceramic, crushed concrete, and crushed red brick as granular pile materials with partial geotextile encasement increase by about $13.4 \%, 15.3 \%, 21.7 \%$, and $30.3 \%$, respectively compared to the very soft clay reinforced with conventional granular piles.

The total geogrid encasement $(\mathrm{X}=\mathrm{L})$ improves the ultimate bearing capacity of very soft clay by about $4.4 \%, 2 \%, 4.6 \%$, and $8.4 \%$, respectively for basalt, crushed ceramic, crushed concrete, and crushed red brick granular pile compared to the partial geogrid encasement $(\mathrm{X}=0.5 \mathrm{~L})$. In the case of using geotextile, increase the length of the encasement from $\mathrm{X}=0.5 \mathrm{~L}$ to $\mathrm{X}=\mathrm{L}$ increase the ultimate bearing capacity by about $17.4 \%, 14.2 \%$, $19 \%$, and $22.6 \%$, respectively for basalt, crushed ceramic, crushed concrete, and crushed red brick as granular pile materials. The use of floating granular pile with geotextile encasement is more efficient than using geogrid for total and partial encasement by a range of about $19.9-29.4 \%$ and $6.6-13.7 \%$, respectively for all granular pile materials used. 


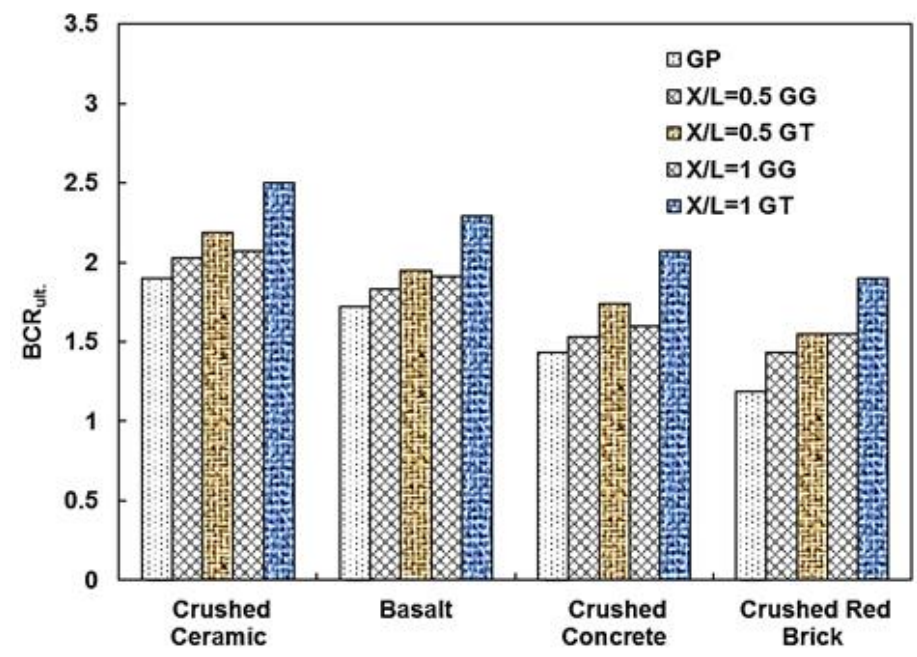

Figure (25): Effect of encasement length and type on $\mathrm{BCR}_{\mathrm{ult}}$ of the very soft clay reinforced with encased floating granular pile with different pile material.

\section{Conclusions}

Based on test results of the performed experimental work, the following conclusions can be drawn:

1. Using a sand pad reduces the settlement and increases the bearing capacity of very soft clay soil. Using a sand pad with a thickness of 30 $\mathrm{mm}$ increases the bearing capacity of very soft clay by $100 \%$.

2. Test results showed that using encased granular pile is better than using a conventional granular pile for very soft clay. soils. Using either geotextile or geogrid encasement improves the very soft clay soil for all pile materials used.

3. Using geogrid as a total encasement for end bearing granular piles improves the very soft clay soil for all pile materials used by about 18.1-26.6\% compared to conventional granular piles. Using geotextile as a total encasement for end bearing granular piles improves the very soft clay soil for all pile materials used by about $0.5-14.5 \%$.

4. Using geogrid encasement is better than using geotextile for total encased end bearing granular pile by a range of about $10.6-21.4 \%$. That may refer to the higher stiffness of geogrid facilitates the maximum transfer of load to the bottom of the granular pile which is resting on hard strata.

5. The use of floating granular pile with geotextile encasement is more useful than using geogrid for total and partial encasement by a range of about $19.9-29.4 \%$ and $6.6-13.7 \%$, respectively.

6. Using partial encasement is more efficient than using total encasement based on the economic point of view. The ultimate bearing capacity decrease for geotextile encasement and geogrid encasement by a range of $12.4-18.4 \%$ and 1.9 $7.7 \%$, respectively compared to total encasement granular piles using different granular pile materials in the range of this study.

\section{References}

[1] R. D. Barksdale and R. C. Bachus, "Design and Construction of Stone Column," National Technical Information, Virginia, USA, 1983.

[2] H. J. Priebe, "Die Bemessung von Rttelstopfverdichtungen," Bautechnik, vol. 72, no. H3, 1995.

[3] J. Han and S. L. Ye, "Simplified Method for Consolidation Rate of Stone Column Reinforced Foundation," Journal of Geotechnical and Geoenvironmental Engineering, vol. 127, no. 7, pp. 597-603, 2001.

[4] E. R. Orekanti and G. V. Dommaraju, "LoadSettlement Response of Geotextile Encased Laterally Reinforced Granular Piles in Expansive Soil Under Compression," International Journal of Geosynthetics and Ground Engineering, vol. 2019, no. 3, 2019.

[5] J. M. O. Hughes and N. J. Withers, "Reinforcing of Soft Cohesive Soils with Stone Columns," Ground Engineering, vol. 7, no. 3, 1974.

[6] D. A. Greenwood, "Mechanical Improvement of Soils Below Ground Surface," in Conference on Ground Engineering, London, UK, 1970.

[7] J. M. McKenna, W. A. Eyre and D. R. Wolstenholme, "Performance of an Embankment Supported by Stone Columns in Soft Ground," Geotechnique, vol. 251, pp. 51-59, 1975.

[8] F. Strabenwesen, "Leaflet for Subsoil Improvement 
Using Depth vibrators," 1979.

[9] J. Gniel and A. Bouazza, "Improvement of Soft Soils Using Geogrid Encased Stone Columns," Journal of Geotext Geomembr, vol. 27, pp. 167-175, 2009.

[10] K. Ali, J. T. Shahu and K. G. Sharma, "Model Tests on Single and Groups of Stone Columns with Different Geosynthetic Reinforcement Arrangement," Geosynthetics International, vol. 21, no. 2, pp. 103-118, 2014.

[11] S. Murugesan and K. Rajagopal, "Model Tests on Geosynthetic Encased Stone Columns," Geosynthetic International, vol. 224, no. 6, pp. 349358, 2007.

[12] S. Murugesan and K. Rajagopal, "Studies on the Behaviour of Single and Group of Geosynthetic Encased Stone Columns," Journal of Geotechnical and Geoenvironmental Engineering, vol. 136, no. 1, 2010.

[13] R. Shivashankar, M. R. Dheerendra-Babu, S. Nayak and R. Manjunath, "Stone Columns with Vertical Circumferential Nails: Laboratory Model Study," Geotechnical and Geological Engineering, vol. 28, no. 5, pp. 695-706, 2010.

[14] M. Gu, L. Hao, L. Zhang and J. Han, "Effect of Geogrid Encasement on Lateral and Vertical Deformation of Stone Coulmns in Model Tests," Geosynthetics International, vol. 23, no. 2, pp. 100112, 2016.

[15] S. Sathish, O. P. Yadav and M. Deepak, "Soft Ground Improvement Using Stone Columns - A Field Trial.," in "Proc., Indian Geotech.Conf, Vadodara, India, 1997.

[16] A. P. Ambily, R. Shailesh and Gandhi, "Behavior of Stone Columns Based on Experimental and FEM Analysis," Journal of Geotechnical and Geoenvironmental Engineering, vol. 133, no. 4, 1 April 2007.

[17] J. T. Shahu, M. R. Madhav and A. Hayashi, "Analysis of Soft Ground Granular Pile: Granular Mat System," Comput. Geotech, pp. 45-62, 2000.

[18] R. R. Goughnour and A. A. Bayuk, "A Field Study of Long-term Settlements of Loads Supported by
Stone Columns in Soft Ground," in Int. Conf. on Soil Reinforcement, Paris, 1979.

[19] E. A. Emam, "Behavior of Rigid Footings Resting on Soft Clay Soil Improved by Floating Granular Piles," Ph. D. Thesis, Faculty of Engineering, Menoufia University, Menoufia, Egypt, 2017.

[20] J. K. Michell, "Soil Improvement - Stat of the Art Report," in 10th International Conference on Soil Mechanics and Foundation Engineering, 1981.

[21] A. Arulrajah, M. M. Disfani, V. Suthagaran and M. Imteaz, "Select Chemical and Engineering Properties of Waste Water Biosolids," Waste Management, vol. 31, no. 12, pp. 2522-2526, 2011.

[22] T. Aatheesan, A. Arulrajah, G. Newman, M. W. Bo and J. Wilson, "Crushed Brick Blends with Crushed Concrete for Pavement Subbase and Drainage Applications," Australian Geomechanics, vol. 44, no. 2, pp. 65-72, 2009.

[23] M. M. Disfani, A. Arulrajah, M. W. Bo and N. Sivakugan, "Environmental Risks of Using Recycled Crushed Glass in Road Applications," Journal of Cleaner Production, vol. 20, no. 1, pp. 170-179, 2012.

[24] D. A. T. Zekkos, A. George, J. D. Bray, A. Grizi and A. Theodoratos, "Large-scale Direct Shear Testing of Municipal Solid Waste," Waste Management, vol. 30, no. 8-9, pp. 1544-1555, 2010.

[25] A. A. Youssef, A. M. Abdel-Galel and E. A. Emam, "Behavior of Soft Clay Soil Reinforced by Floating Granular Piles with Different Materials," Journal of Scientific and Engineering Research, vol. 4, no. 7, pp. 25-40, 2017.

[26] C. L. Da-Fabiana, S. M. Dos Rosângela, L. V. Kamilla and L. Bernucci, "Laboratory Evaluation of Recycled Construction and Demolition Waste for Pavements," Construction and Building Materials, vol. 25, no. 6, pp. 2972-2979, 2011.

[27] A. A. Khan and P. H. Krishna, "A Study on Load Carrying Capacity of Soft Clays Provided with Granular Piles of Different Materials," in Proceedings of Indian Geotechnical Conference IGC-2014, Kakinada, India, 2014. 